\title{
PENINGKATAN PENGETAHUAN MASYARAKAT DENGAN EDUKASI VAKSINASI COVID-19
}

\author{
Dian Kartikasari* ${ }^{*}$; Emi Nurlaela ${ }^{2}$; Neti Mustikawati ${ }^{3}$ \\ 1, 2,3 Program Studi Sarjana Keperawatan dan Pendidikan Profesi Ners Fakultas Ilmu Kesehatan \\ Universitas Muhammadiyah Pekajangan Pekalongan; \\ Jl. Raya Ambokembang No.8 Kambang Tengah, Kudungwuni, Pekalongan, Jawa Tengah
}

\begin{abstract}
Abstrak
Vaksinasi Covid 19 merupakan salah satu pencegahan penularan Covid 19. Minimnya pengetahuan masyarakat akan vaksinasi Covid 19 dan kurangnya informasi tentang vaksinasi Covid 19 menjadi salah satu faktor penyebab masyarakat takut akan vaksin. Tujuan dari kegiatan pengabdian kepada masyarakat adalah memberikan edukasi tentang vaksinasi covid 19. Penyuluhan dilakukan melalui metode paparan, tanya jawab, pengisian kuesioner. Data diambil melalui pengisian kuesioner, wawancara dan observasi yang selanjutnya dianalisis secara deskriptif. Terlihat peningkatan pemahaman peserta tentang vaksinasi sebesar 100\% (50 peserta), pemahaman tentang protokol kesehatan sebesar $100 \%$ (50 peserta), pemahaman tentang gejala yang ditimbulkan setelah melakukan vaksinasi Covid 19 sebesar 90\% (45 peserta), dan pemahaman tentang penatalaksanaan yang bisa dilakukan di rumah setelah melakukan vaksinasi Covid 19 sebesar $90 \%$ (45 peserta).
\end{abstract}

Kata kunci: edukasi, pengetahuan, masyarakat, vaksinasi, covid-19

\begin{abstract}
[INCREASING KNOWLEDGE CITIZEN WITH COVID-19 VACCINATION EDUCATION] The Covid 19 vaccination is one of the prevention of the transmission of Covid 19. The lack of public knowledge about the Covid 19 vaccination and the lack of information about the Covid 19 vaccination is one of the factors that causes people to be afraid of vaccines. The purpose of community service activities is to provide education about covid 19 vaccination. Counseling is carried out through exposure, question and answer methods, filling out questionnaires. Data were taken through filling out questionnaires, interviews and observations which were then analyzed descriptively. There was an increase in participants' understanding of vaccination by $100 \%$ (50 participants), understanding of health protocols by 100\% (50 participants), understanding of the symptoms caused after vaccinating Covid 19 by $90 \%$ (45 participants), and understanding of the management that can be done carried out at home after vaccinating for Covid 19 by $90 \%$ (45 participants).
\end{abstract}

Keywords: counseling, knowladge citizen, vaccination, covid-19

\section{Pendahuluan}

Wabah penyakit yang disebabkan oleh virus corona atau biasa yang disebut dengan Covid 19 telah ditetapkan sebagai pandemik global oleh World Health Organization (WHO) pada bulan Maret 2020 (Rachman \& Pramana, 2020). Covid 19 merupakan penyakit jenis baru yang belum pernah diidentifikasi sebelumnya pada manusia. Berdasarkan bukti ilmiah, Covid

*) Correspondence Author (Dian Kartikasari)

E-mail: dian.kartikasari1989@gmail.com
19 dapat menular dari manusia ke manusia melalui percikan batuk atau bersin (Agusta \& Letuna, 2021). Orang yang paling berisiko tertular penyakit ini adalah orang yang kontak erat dengan pasien Covid 19 termasuk yang merawat pasien Covid 19. Pasien yang mengalami Covid 19 pada umumnya mengalami gejala-gejala seperti batuk, sesak napas, dan demam (Makmun \& Hazhiyah, 2020).

Vaksin bukan hanya digunakan untuk memutus rantai penyebaran suatu penyakit juga sebagai perlindungan untuk masyarakat yang 
telah dilakukan vaksinasi (Listina et al., 2021). Banyak sekali manfaat vaksinasi, diantaranya sebagai pencegahan dan pemutus penyebaran suatu penyakit pada masa yang akan datang, juga dapat memperkecil dampak dari penyebaran virus. Salah satu cara yang bisa dilakukan untuk memutus rantai penyebaran Covid 19 adalah dengan melakukan vaksinasi (Kartikawati \& Mayarni, 2021).

Untuk mendukung adanya pencegahan penularan Covid 19 maka dilakukan dengan tindakan vaksinasi. Vaksinasi tersebut dibutuhkan suatu promosi atau pendidikan kesehatan yang bertujuan untuk memberikan informasi kesehatan tentang vaksinasi Covid 19 sehingga diharapkan dapat memutus rantai penyebaran Covid 19 (Aldilawati \& Hidayat, 2021). Selain itu, langkah protokol kesehatan yang menjadi suatu kebiasaan baru di masyarakat akibat adanya Covid 19 adalah gerakan pakai masker, mencuci tangan dengan menggunakan sabun, dan menjaga jarak kurang sehingga angka paparan Covid 19 terus meningkat (Hidayat et al., 2021)

Salah satu faktor yang menyebabkan masyarakat tidak patuh karena kurangnya informasi yang tersampaikan ke masyarakat (Nurdiana et al., 2021). Respon masyarakat untuk aktif dalam melakukan pencegahan penyebaran Covid 19 belum optimal. Walaupun Indonesia sudah dalam keadaan darurat, masih di beberapa tempat mengumpulkan banyak orang di satu tempat yang bisa menjadi mediator untuk penyebaran virus Covid 19 dengan skala yang lebih besar (Zulfa \& Kusuma, 2020).

Mengingat hal tersebut, sebagai upaya untuk proteksi sekaligus deteksi dini dan perawatan yang cepat untuk menghentikan penyebaran Covid 19, maka berbagai negara telah berkomitmen untuk melibatkan pemerintah sampai akademisi untuk menciptakan vaksin Covid 19. Sejauh ini sudah banyak vaksin Covid 19 yang diberikan untuk melawan virus Covid 19 (Makmun \& Hazhiyah, 2020).

Kegiatan vaksinasi harus mempertimbangkan beberapa aspek diantaranya kelayakan vaksin, resiko pemakaian, tahapan pemberian vaksin, serta prosedur pemberian vaksin ke masyarakat. Aspek tersebut harus dipertimbangkan supaya kegiatan vaksinasi tersebut berjalan dengan baik dan tidak ada kerugian yang akan dialami masyarakat (Rachman \& Pramana, 2020).

Hal inilah yang menjadikan latar belakang tim Universitas Muhammadiyah Pekajangan Pekalongan melakukan kegiatan dengan memberikan edukasi mengenai pentingnya vaksinasi Covid 19. Hal ini bertujuan supaya masyarakat memperoleh informasi yang sesuai serta tidak timbul ketakutan mengenai pemberian vaksin Covid 19. Selain itu juga sebagai upaya pencegahan dan penyebaran Covid 19.

\section{Metode}

Kegiatan pengabdian masyarakat ini dilaksanakan di Kampus 2 Fakultas Ilmu Kesehatan Universitas Muhammadiyah Pekajangan Pekalongan. Sosialisasi mengenai edukasi pentingnya vaksinasi tersebut dilakukan khususnya pada masyarakat mengenai vaksinasi terutama dalam pencegahan Covid 19. Permasalahan dari dirumuskan menjadi 2 bagian, yaitu minimnya informasi mengenai vaksinasi Covid 19 dan menumbuhkan sikap peduli dalam melakukan tahap pencegahan penyebaran Covid 19.

Tujuan yang ingin dicapai adalah memperoleh informasi yang sesuai serta tidak ada lagi ketakutan masyarakat mengenai pemberian vaksin seperti informasi mengenai kemungkinan yang terjadi setelah pemberian vaksin beserta pencegahannya sehingga masyarakat bersedia dilakukan vaksinasi kembali.

Kegiatan yang telah dilakukan dalam pengabdian ini yaitu terdiri dari 3 tahapan, yaitu:

a. Tahap persiapan

Tahapan ini dimulai dengan pemetaan lokasi dengan meminta izin serta koordinasi dengan Universitas Muhammadiyah Pekajanagn Pekalongan beserta Lembaga Penelitian dan Pengabdian Masyarakat (LPPM) Universitas Muhammadiyah Pekajangan Pekalongan, melakukan pendataan serta analisis masalah dan solusi, penyebaran kuesioner tingkat pemahaman masyarakat tentang gejala dan penatalaksanaan yang bisa dilakukan di rumah setelah vaksninasi Covid 19 (pre test).

b. Tahap pelaksanaan

Tahapan ini dilaksanakan dalam bentuk edukasi dengan metode paparan dan tanya jawab mengenai gejala dan penatalaksanaan yang bisa dilakukan di rumah setelah vaksninasi Covid 19 serta pengisian kuesioner tingkat pemahaman masyarakat tentang gejala dan penatalaksanaan yang bisa dilakukan di rumah setelah vaksninasi Covid 19 (post test). 
c. Tahap evaluasi

Tahapan ini merupakan tahapan evaluasi hasil kuesioner pre test dan post test akan tingkat pemahaman masyarakat mengenai gejala dan penatalaksanaan yang bisa dilakukan di rumah setelah vaksinasi Covid 19 dan pelaporan hasil kegiatan.

Penyebaran kuesioner dilaksanakan sebelum dan setelah kegiatan dengan metode random sampling yang dilakukan terhadap 50 orang. Kuesioner pre test dan post test yang diberikan ke masyarakat dibagi menjadi beberapa kategori yaitu:

a. Pemahaman tentang vaksinasi.

b. Pemahaman tentang protokol kesehatan.

c. Pemahaman tentang gejala yang ditimbulkan setelah melakukan vaksinasi Covid 19.

d. Pemahaman tentang penatalaksanaan yang bisa dilakukan di rumah setelah melakukan vaksinasi Covid 19.

\section{Hasil dan Pembahasan}

\section{Tahap Persiapan}

Pada tahap persiapan kegiatan pengabdian masyarakat, dilakukan pemetaan lokasi. Penggalian informasi pada wilayah sasaran sudah mendapatkan izin dari Lembaga Penelitian dan Pengabdian Masyarakat (LPPM) Universitas Muhammadiyah Pekajangan Pekalongan. Setelah informasi detail yang diperlukan didapatkan selanjutnya dilakukan penyebaran kuesioner tingkat pemahaman masyarakat tentang tentang gejala yang ditimbulkan setelah melakukan vaksinasi Covid 19 (pre test) kemudian dilakukan, untuk kemudian dilakukan analisa layak atau tidak untuk dilakukan edukasi. Setelah dilakukan penilaian, kemudian dilanjutkan dengan pemilihan waktu dan tempat pelaksanaan serta pemberian informasi pada peserta.

Menggunakan kuesioner mengenai tingkat pemahaman peserta sebelum dilakukan vaksin Covid 19 dilaksanakan didapatkan bahwa ratarata peserta belum mengetahui tentang vaksin covid 19. Berdasarkan analisa pemahaman awal rata-rata $10 \%$ (sangat rendah), sehingga termotivasi untuk diadakannya kegiatan pengabdian kepada masyarakat $(\mathrm{PkM})$ dalam bentuk penyuluhan akan vaksin Covid 19.

Kuesioner tingkat pemahaman masyarakat dibagi menjadi beberapa kategori disertai hasil analisa sebelum kegiatan pengabdian kepada masyarakat dilaksanakan seperti:

a. Pemahaman tentang vaksinasi $(80 \%$ tidak paham, 20\% paham). b. Pemahaman tentang protokol kesehatan $(80 \%$ tidak paham, 20\% paham).

c. Pemahaman tentang gejala yang ditimbulkan setelah melakukan vaksinasi Covid 19 (90\% tidak paham, $10 \%$ paham).

d. Pemahaman tentang penatalaksanaan yang bisa dilakukan di rumah setelah melakukan vaksinasi Covid 19 (90\% tidak paham, 10\% paham).

Penilaian dikategorikan tidak paham apabila peserta memberikan jawaban yang salah dari beberapa pilihan jawaban yang disediakan. Kategori tidak paham diberikan kepada jawaban yang peserta yang benar akan tetapi kurang tepat. Sedangkan kategori paham diberikan kepada jawaban peserta yang benar dan tepat. Dari hasil analisa jawaban peserta sebelum materi diberikan adalah didapatkan hasil kurang memuaskan dengan sebagian besar peserta sangat kurang (kurang paham) akan vaksinasi covid 19. Hal inilah yang mendasari kegiatan pengabdian kepada masyarakat ini dilaksanakan pada responden.

\section{Tahap Pelaksanaan}

Kegiatan pengabdian masyarakat berlangsung pada tanggal 3-5 Agustus 2021 berlokasi di Kampus 2 Fakultas Ilmu Kesehatan Universitas Muhammadiyah Pekajangan Pekalongan Jl. Raya Ambokembang No. 8 Pekalongan 51172. Peserta berasal dari berbagai kota dari berbagai jenis profesi dan latar belakang pendidikan. Sejumlah 50 orang dengan rentang usia diatas 18 tahun. Kegiatan pengabdian kepada masyarakat ini dimulai pukul 08.00 WIB hingga pukul 15.00 WIB.

Kegiatan pengabdian kepada masyarakat dapat dilihat melalui dokumentasi kegiatan yang ditunjukkan pada gambit-gambar berikut. Edukasi dilakukan dengan memberikan informasi mengenai pemahaman tentang gejala yang ditimbulkan setelah melakukan vaksinasi Covid 19, seperti vaksinasi, protokol kesehatan, gejala yang ditimbulkan setelah melakukan vaksinasi Covid 19, dan penatalaksanaan yang bisa dilakukan di rumah setelah melakukan vaksinasi Covid 19 (Gambar 1).

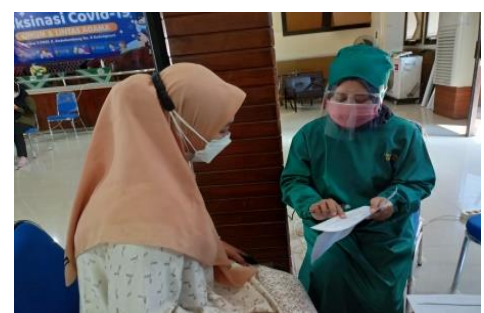

Gambar 1. Edukasi Vaksinasi Covid 19 
Setelah edukasi dilakukan, juga dilakukan sesi tanya jawab baik sesi tanya jawab setelah paparan maupun tanya jawab selama proses edukasi. Sesi tanya jawab dengan memberikan kesempatan bertanya mengenai paparan materi. Sesi pertanyaan juga dilakukan peserta saat edukasi berlangsung (Gambar 2).

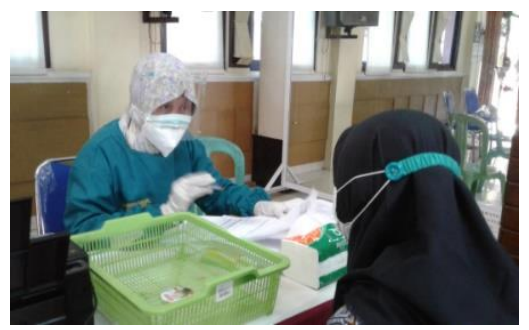

Gambar 2. Sesi Pertanyaan

Sesi pertanyaan juga dilakukan peserta pada kegiatan edukasi berlangsug, masyarakat diberikan pemahaman akan pertanyaan yang mereka ajukan untuk mengetahui tentang vaksinasi Covid 19. Pemahaman peserta akan vaksinasi Covid 19 dengan cara ini merupakan tahapan awal untu membuat masyarakat agar lebih mengetahui dan tidak takut akan vaksinasi Covid 19.

\section{Tahap Evaluasi}

Pada tahap ini dilakukan analisa terhadap hasil pre test dan post test masyarakat yang hasilnya dibandingkan dengan pre test. Dari hasil analisa setelah kegiatan pengabdiam masyarakat didapatkan presentase tingkat pemahaman peserta di setiap pertanyaan, didapatkan kenaikan dengan rata-rata sebesar $90 \%$ dari tingkat pemahaman awal, sehingga didapatkan keseluruhan peserta sebagian besar sudah memahami akan pentingnya vaksinasi covid 19 secara baik dan benar (Gambar 3).

Tingkat Pemahaman Peserta Terhadap Vaksinasi Covid 19

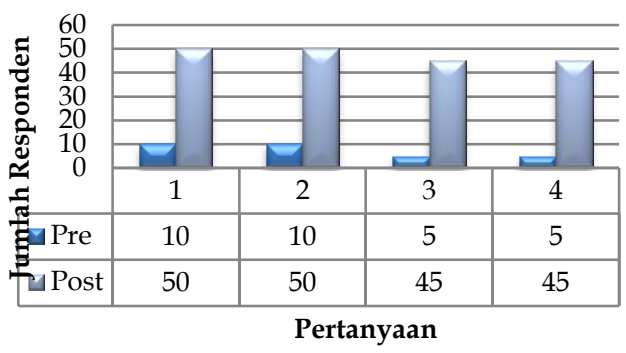

Gambar 3. Tingkat Pemahaman Peserta Terhadap Vaksinasi Covid 19
Berdasarkan hasil analisa awal (sebelum kegiatan pengabdian masyarakat), peserta yang mampu memahami tentang vaksinasi sebesar $20 \%$ (10 peserta), pemahaman tentang protokol kesehatan sebesar 20\% (10 peserta), pemahaman tentang gejala yang ditimbulkan setelah melakukan vaksinasi Covid 19 sebesar 10\% (5 peserta), dan pemahaman tentang penatalaksanaan yang bisa dilakukan di rumah setelah melakukan vaksinasi Covid 19 sebesar $10 \%$ (5 peserta).

Setelah kegiatan pengabdian masyarakat dilakukan, terlihat peningkatan pemahaman peserta tentang vaksinasi sebesar 100\% (50 peserta), pemahaman tentang protokol kesehatan sebesar $100 \%$ (50 peserta), pemahaman tentang gejala yang ditimbulkan setelah melakukan vaksinasi Covid 19 sebesar 90\% (45 peserta), dan pemahaman tentang penatalaksanaan yang bisa dilakukan di rumah setelah melakukan vaksinasi Covid 19 sebesar $90 \%$ (45 peserta).

Hal ini sejalan dengan penelitian (Rosidin et al., 2021) yang menyatakan adanya peningkatan pengetahuan masyarakat tentang vaksinasi Covid 19. Peningkatan pengetahuan melalui kegiatan pendidikan kesehatan dapat dilakukan selama kegiatan tersebut dilaksanakan dengan menggunakan media yang tepat, menarik dan mudah dipahami. Dalam kegiatan pendidikan kesehatan, tim pengabdian menggunakan media penyuluhan berupa poster dan leaflet. Penyediaan media serta metodologi pendidikan yang dinamis serta dialogis sangat diperlukan bagi pengembangan potensi peserta didik secara optimal. Hal ini disebabkan karena potensi peserta didik akan lebih terangsang bila dibantu dengan sejumlah media atau sarana dan prasarana yang mendukung proses interaksi yang sedang dilaksanakan.

Kegiatan pengabdian kepada masyarakat secara keseluruhan berjalan dengan baik dan lancar. Hal ini berdasarkan jumlah peserta yang hadir pada kegiatan tersebut dan tanggapan dari peserta yang berpendapat bahwa kegiatan ini sangat bermanfaat dan menambah wawasan mengenai pentingnya vaksinasi covid 19 . Berdasarkan hasil analisa kepuasan peserta terhadap kegiatan pengabdian kepada masyarakat didapatkan hasil baik sekali sebesar $50 \%$, baik 30\%, dan cukup 20\%. Hal ini disimpulkan bahwa kegiatan ini mampu memberikan kepuasan kepada masyarakat baik dari segi materi yang disampaikan, respon atas pertanyaan serta manfaat dari hasil yang didapatkan. 


\section{Simpulan dan Saran}

Peningkatan pengetahuan masyarakat dengan edukasi vaksinasi Covid 19 di Universitas Muhammadiyah Pekajangan Pekalongan berjalan dengan lancar. Hasil analisa menunjukkan adanya peningkatan pengetahuan msyarakat tentang vaksinasi covid 19 setelah dilakukan edukasi. Dengan adanya peningkatan pengetahuan tersebut, diharapkan kesadaran masyarakat meningkat terhadap pencegahan covid 19 yang salah satunya dengan melakukan vaksinasi.

Kegiatan yang sudah dilaksanakan diharapkan dapat berkelanjutan vaksinasi berikutnya oleh masyarakat khususnya di Kabupaten Pekalongan. Pihak terkait seperti Puskesmas di wilayah Kabupaten Pekalongan diharapkan dapat melakukan pembinaan secara intensif kepada masyarakat sehingga perilaku yang sudah baik dapat dipertahankan. Kesadaran masyarakat terhadap vaksinasi covid 19 harus terus digalakan, tidak boleh lengah dan terus melakukan pendampingan kepada masyarakat.

\section{Ucapan Terima Kasih}

Terima kasih disampaikan kepada Lembaga Penelitian dan Pengabdian Kepada Masyarakat Universitas Muhammadiyah Pekajangan Pekalongan yang telah memfasilitasi kegiatan edukasi vaksinasi Covid 19. Ucapan terima kasih dapat juga disampaikan kepada pihak-pihak yang membantu pelaksanaan edukasi vaksinasi Covid 19 yang tidak dapat kami sebutkan satu persatu.

\section{Daftar Pustaka}

Agusta, M., \& Letuna, N. (2021). Instragram Sebagai Media Edukasi Vaksin Covid19 Di Indonesia Instragram As an Educational Media for Covid-19 Vaccines in Indonesia. Jurnal Communio: Jurnal Ilmu Komunikasi, 10(1), 88-106.

Aldilawati, S., \& Hidayat, R. (2021). Edukasi Vaksinasi Covid-19 dan Penerapan 5M Dalam Menanggulangi Penularan Covid-19 di Desa Borisallo Kabupaten Gowa. Idea Pengabdian Masyarakat, 1(01), 01-06.

https://doi.org/10.53690/ipm.v1i01.23
Hidayat, M., Mahalayati, B. R., \& Sadikin, H. (2021). Peran Promosi Kesehatan Dalam Edukasi Tenaga Kesehatan Di Masa Pasca Vaksinasi Covid-19 di Kabupaten Tanah Laut. Jurnal Sains Sosio Humaniora, 5(1), 339-345.

Kartikawati, E., \& Mayarni, M. (2021). Edukasi Vaksinasi Covid-19 Bagi Kelompok Aisyiah Ranting Kukusan Depok. SELAPARANG Jurnal Pengabdian Masyarakat Berkemajuan, 4(3), 650. https://doi.org/10.31764/jpmb.v4i3.51 82

Listina, O., Cahya Chaerunnisa, D., Program Studi Farmasi S-, D., Bhakti Mandala Husada Slawi, Stik., \& Program Studi Farmasi S-, M. (2021). " Di Panti Asuhan Zainab Masykuri Kota Tegal. JABI: Jurnal Abdimas Bhakti Indonesia, 2(1).

Makmun, A., \& Hazhiyah, S. F. (2020). Paragraf 1. Molucca Medica, 13, 52-59.

Nurdiana, A., Marlina, R., \& Adityasning, W. (2021). Berantas Hoax Seputar Vaksin Covid-19 Melalui Kegiatan Edukasi dan Sosialisasi Vaksin Covid-19. ABDIMAS: Jurnal Pengabdian Masyarakat, 4(1), 489495.

https://doi.org/10.35568/abdimas.v4i 1.1175

Rachman, F. F., \& Pramana, S. (2020). Analisis Sentimen Pro dan Kontra Masyarakat Indonesia tentang Vaksin COVID-19 pada Media Sosial Twitter. Health Information Management Journal, 8(2), 100-109.

Rosidin, U., Yani, D. I., Lukman, M., \& Mulya, A. P. (2021). Pendidikan Kesehatan Tentang Pencegahan Covid 19 Di Desa Cilembu Kecamatan Pamulihan Kabupaten Sumedang. Dharmakarya, 10(3), 258. https://doi.org/10.24198/dharmakary a.v10i3.32639

Zulfa, F., \& Kusuma, H. (2020). Upaya Program Balai Edukasi Corona Berbasis Media Komunikasi dalam Pencegahan Penyebaran Covid-19. Jakp: Jurnal Abdimas Kesehatan Perintis, 2(1), 21-23. 